\title{
Coupled onshore erosion and offshore sediment loading as causes of lower crust flow on the margins of South China Sea
}

\author{
Peter D. Clift ${ }^{1,2^{*}}$
}

\begin{abstract}
Hot, thick continental crust is susceptible to ductile flow within the middle and lower crust where quartz controls mechanical behavior. Reconstruction of subsidence in several sedimentary basins around the South China Sea, most notably the Baiyun Sag, suggests that accelerated phases of basement subsidence are associated with phases of fast erosion onshore and deposition of thick sediments offshore. Working together these two processes induce pressure gradients that drive flow of the ductile crust from offshore towards the continental interior after the end of active extension, partly reversing the flow that occurs during continental breakup. This has the effect of thinning the continental crust under super-deep basins along these continental margins after active extension has finished. This is a newly recognized form of climate-tectonic coupling, similar to that recognized in orogenic belts, especially the Himalaya. Climatically modulated surface processes, especially involving the monsoon in Southeast Asia, affects the crustal structure offshore passive margins, resulting in these "load-flow basins". This further suggests that reorganization of continental drainage systems may also have a role in governing margin structure. If some crustal thinning occurs after the end of active extension this has implications for the thermal history of hydrocarbon-bearing basins throughout the area where application of classical models results in over predictions of heatflow based on observed accommodation space.
\end{abstract}

\section{Introduction}

The process of continental crustal extension and the formation of sedimentary basins have been quantified and described using a number of different approaches that explain how strain is accommodated in the continental lithosphere (McKenzie 1978; Royden and Keen 1980; Tankard and Welsink 1987; Wernicke 1985). Although it is possible to think of rifted, passive continental margins as being simply extreme examples of this type of intra-continental deformation, culminating in seafloor spreading as extension reaches a maximum (beta $=$ infinity), there is evidence to indicate that the style of strain accommodation may be different when breakup occurs. Simple application of uniform extension models (i.e. when the amount of extension is the same at all depths

\footnotetext{
*Correspondence: pclift@lsu.edu

${ }^{1}$ Department of Geology and Geophysics, Louisiana State University,

Baton Rouge, LA 70803, USA

Full list of author information is available at the end of the article
}

in a continental plate) to passive margins has resulted in the identification of subsidence anomalies, usually in the form of greater subsidence than would be expected from the degree of extension as measured on normal faults identified within the upper crust in seismic profiles (Driscoll and Karner 1998; Davis and Kusznir 2004; Clift et al. 2002; Boillot et al. 1988; Lister et al. 1991). Not all brittle extension is identified on industrial style, deeppenetrating seismic reflection profiles (Walsh et al. 1991). Nonetheless, the anomalies found in passive margins are so large that even accounting for this uncertainty does not resolve the mismatch between the total amount of subsidence recorded. The anomalies require high degrees of total crustal thinning and a higher degree of upper crust extension than actually observed (Clift et al. 2002).

Early attempts to address this conundrum involved invoking simple shear type mechanisms, similar to those developed by Wernicke (1985) and colleagues in the Basin and Range province of the Western United States 
(Lister et al. 1991; Boillot et al. 1988; Whitmarsh et al. 2001). In this scenario high degrees of subsidence could be explained if the lower crust was extended more than the upper crust as a result of the passive margin being located in the upper plate of a simple shear system. This would imply contrasting reduced subsidence anomalies on the facing conjugate margin. However, as noted by Driscoll and Karner (1998), although many marine geologists were keen to label the particular margin that they were studying as being in the upper plate position, very few seem to consider the possibility of a lower plate setting. Driscoll and Karner (1998) labeled this phenomenon as the "upper plate paradox" because more often than not conjugate margins both exhibited the "upper plate" characteristics.

\section{Lower crustal flow}

One possible solution to the upper plate paradox is to understand the role of ductile flow in the ductile part of the crust. In regions where the crust was thick and/ or the heatflow is high there is the possibility of large thicknesses of middle and/or lower crust that are ductile (McKenzie et al. 2000) (Fig. 1). If this type of crust is common then this allows for the possibility of non-uniform strain accommodation (i.e., where the amount of extension is not the same through the plate). There is certainly abundant evidence that such thick, warm crust is susceptible to flow during the formation of wide rifts, such as the Basin and Range (Buck 1991). Zuber et al. (1986) recognized that although the topography of the Basin and Range was corrugated, the Moho underlying that area was remarkably flat, seemingly at odds with the normal

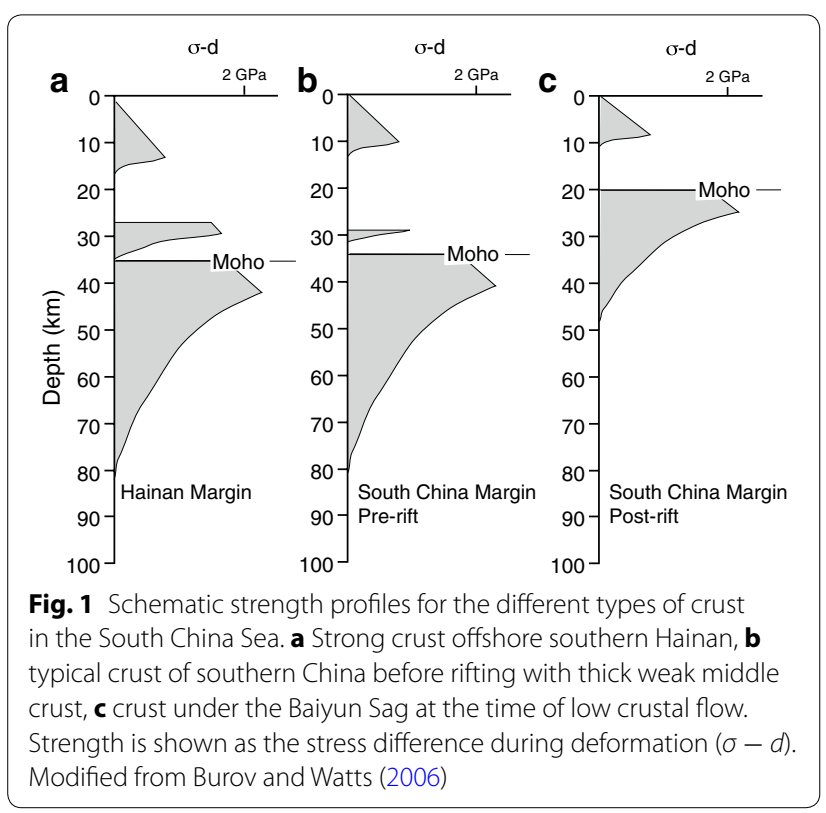

prediction of local isostatic equilibrium. These workers suggested that the reason for the lack of Moho topography was because of flow in the lower crust removing the hills and troughs in the Moho after extension had ceased and because the ductile lower crust flowed away from the deepest crusts keels.

Ductile crustal flow is also thought to be important in many orogenic settings. Clark and Royden (2000) proposed that the smooth, low-gradient eastern flanks of the Tibetan Plateau are largely caused by flow of the middle crust away from the thickened crust in the center of Tibet towards the southeast. Such flow would be driven by the gravitational potential of the thick crust under Tibet compared to the relatively thin crust under southern China and Indochina. At the same time, southward flow of Tibetan middle crust is inferred to play a role in the formation of the Greater Himalayan Crystalline Sequence (Beaumont et al. 2001). Focused erosion along the southern flank of the plateau has been proposed as the mechanism that causes the high degrees of denudation seen in the Greater Himalaya in which shallow rocks have been removed allowing the ductile mid crust to flow to the surface in a well-defined channel, which is bounded by brittle faults at shallow levels (Harris 2007; Hodges 2006; Godin et al. 2006). Although there are significant criticisms of the channel flow model for the Himalaya (Harrison 2006; Webb et al. 2007) the concept that thick, weak crust might be susceptible to flow is common in both convergent and extensional plate settings. However, this concept has not yet been fully appreciated in offshore zones.

\section{South China Sea}

The South China Sea has become a natural laboratory for understanding the processes of continental breakup because of the ease by which conjugate margins might be compared. Furthermore, rifting was terminated during active propagation as result of the collision of the southern Dangerous Grounds margin with Borneo (Hutchison et al. 2000; Clift et al. 2008; Hinz et al. 1989). This basin was formed as a result of extension starting in the Late Cretaceous and accelerating during the Eocene, culminating in breakup and the onset of seafloor spreading likely around $30 \mathrm{Ma}$, at least offshore of southern China (Su et al. 1989; Briais et al. 1993; Ru and Pigott 1986; Franke et al. 2014; Barckhausen et al. 2014). Studies of extension in this system, based on industrial seismic reflection profiles, suggested that the high degrees of subsidence seen, especially in the oceanward parts of the rifted margins around this basin could be explained in terms of depth-dependent extension (Davis and Kusznir 2004; Clift and Lin 2001). The mis-match between upper crustal extension and total crust thinning inferred from 
subsidence increased towards the continent-ocean boundary (Clift et al. 2002; Davis and Kusznir 2004).

In this type of deformation the lower crust is consistently more extended than the upper crust, which explains the large amounts of subsidence that occur following the cessation of active extension. Typically the post-rift is a time normally associated with slowing basement subsidence (McKenzie 1978). The wide nature of the South China Sea rifted margins and the rough bathymetry observed on both sides of the basin suggested that continental extension prior to breakup in this region is comparable to the Basin and Range (Hutchison and Vijayan 2010), i.e. that this is a wide rift that occurred in a thermally warm setting (Clift et al. 2002), consistent with the fact that the extension took place in an area which had been an active continental margin during the Cretaceous (Zhu et al. 2004; Gilder et al. 1996). Critically, seismic profiles on both sides of the basin showed that upper crustal extension was insufficient to explain the subsidence observed and that the degree of this mismatch increases approaching the continent-ocean transition (Clift et al. 2002).

\section{Strength in the lithosphere}

Figure 1 shows estimated strength profiles for both strong and weak parts of the passive margin offshore southern China based on basic models of lithospheric strength (Burov and Watts 2006). Observations of the slope to the basement offshore the central Chinese margin (Pearl River Mouth Basin; Fig. 2) showed low gradients consistent with low degrees of middle crustal viscosity $1 \times 10^{18}$ Pa.s (Clift et al. 2002), comparable to those seen in the asthenosphere (Doglioni et al. 2011). In contrast, south of Hainan in the Qiongdongnan Basin (Fig. 2) steep sides to the basin imply higher degrees of viscosity $\left(1 \times 10^{21}\right.$ Pa.s) (Clift et al. 2002). Such profiles might be expected given the assumed common abundance of quartz in the crust in the case of an active continental margin with typical andesitic and granitic lithologies dominating (Rudnick and Fountain 1995). Because quartz is able to flow in a ductile fashion when hotter than around $300{ }^{\circ} \mathrm{C}$ (Tullis 1979) it might be anticipated that below around $10-15 \mathrm{~km}$ the continental crust could deform in a ductile fashion. The models shown in Fig. 1 factor in the possibility that the lowermost crust may be free from quartz as a result of being composed of cumulate mafic igneous rocks, in which case feldspar would be the controlling mineral. Feldspar is ductile above temperatures of around $500{ }^{\circ} \mathrm{C}$ (Smith 2013) and would be expected to be ductile below depths of around $15-20 \mathrm{~km}$, comprising much of the lower crust, although likely with somewhat higher viscosities than seen in the quartz-bearing mid crust. Nonetheless, given the tectonic setting and best estimates of the andesitic bulk crustal composition the expectation is that crustal flow should have affected this region during the breakup. As extension proceeded to high values thinning of the crust must eventually result in the entire crust becoming brittle so that faults are able to cut completely through it ending the flow (Hayes et al. 1995; Pérez-Gussinyé et al. 2006).

Gravitational considerations would suggest that, as in the case of Eastern Tibet, flow within the continental margin should be from the thick part of the crust towards those parts of the margin where extension was at a maximum (Fig. 3). Such a model requires that some of the crust be incorporated, perhaps being remelted and mixed with new mantle melts, into the oldest oceanic crust following the onset of seafloor spreading, as it cannot be accommodated under the conjugate margin when both are seen to experience excess subsidence. Such reasoning would suggest that this type of deformation should be common in warm lithospheric rift settings and not be unique to the South China Sea.

\section{Woodlark Basin}

I examine the possibility of widespread ductile non-uniform extension by looking at the Woodlark Basin from the Southwest Pacific where a propagating spreading center is tearing apart arc crust in the eastern parts of Papua New Guinea to form a new oceanic basin (Weissel et al. 1982). Although the region is tectonically complicated by a number of small plates that are independently rotating and may also be affected by subduction zones (Baldwin et al. 2012) the region is clearly one of extension within warm orogenic type crust, similar to what was inferred for the South China Sea prior to the onset of seafloor spreading. The Woodlark Basin spreading center rift tip has propagated $>500 \mathrm{~km}$ westward in a stepwise process resulting in the separation of the once contiguous Woodlark and Pocklington Rises (Fig. 4a). Extension across the rift is accommodated on both active lowangle $\left(25-30^{\circ}\right)$ (Abers 2001) and high-angle normal faults (Kington and Goodliffe 2008). West of the Moresby Seamount, which I model in this study, there are exposures of metamorphic core complexes within the active Woodlark Rift (Little et al. 2007).

Figure 4a shows an interpretation of a seismic reflection profile collected perpendicular to the strike of the Woodlark Basin immediately ahead of the new seafloor spreading center (Taylor et al. 1995; Mutter et al. 1996). Figure $4 \mathrm{~b}$ shows the prediction of what this basin would look like if it had formed as a result of extension as applied by the uniform flexural cantilever model of Kusznir et al. (1991) and using the Stretch ${ }^{\mathrm{TM}}$ software of Badley Ashton. In this model the upper crust is deformed in a brittle fashion, but the lower crust stretches in a 


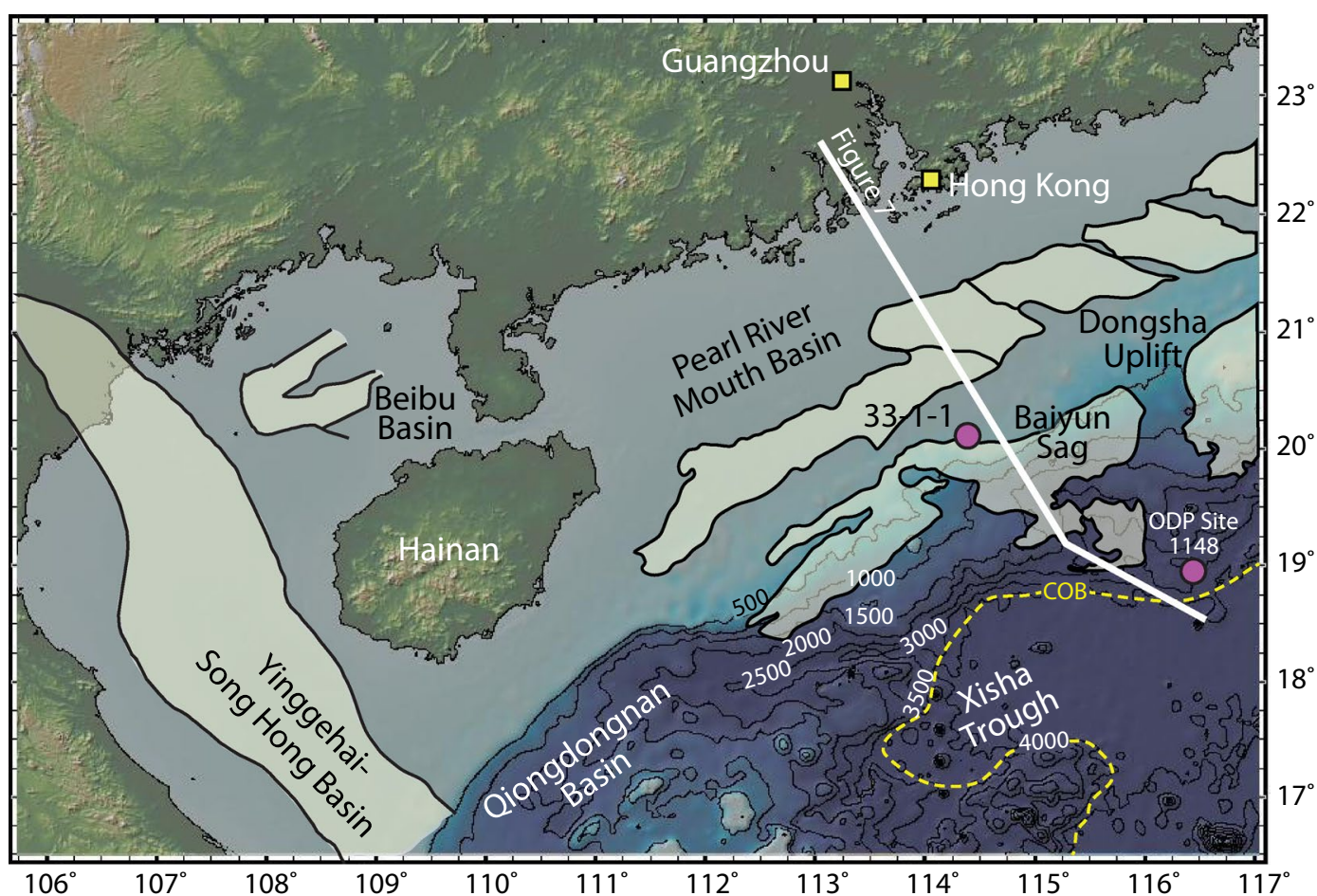

Fig. 2 Shaded bathymetric map showing the major sub-basins discussed in this paper. Map produced using GeoMapApp. Modified from Clift et al. (2015)

more ductile mode over long wavelengths, but with the same degree of total extension, as inferred from the seismically imaged faults, across which total horizontal extension has been measured to form the input to the forward model. The forward model furthermore uses the measured dips on the faults to generate a prediction of basin geometry. The flexural cantilever has been used to successfully model intra-continental rifts (Roberts et al. 1993; Kusznir and Egan 1989) and to identify subsidence anomalies in South China Sea (Clift et al. 2002).

This modeling approach provides a reasonably good reproduction of the shape of the basement at the end of active extension but fails to predict the depth of the basin very accurately. Figure $4 \mathrm{~b}$ shows the prediction that the Moresby Seamount, a structural high in the middle of the rift basin, should rise slightly above sea level, as should some of the structural highs located around the 20-km mark on the profile. Instead, Fig. 4a shows the reality in that neither of these features comes close to sea level, but mostly lies around $1 \mathrm{~km}$ water depth. This mismatch is a robust result that changes slightly depending on how the faults are interpreted on the seismic image but does not disappear if the angle of dip is adjusted or the geometry changed from being planar to listric. How then do we explain the discrepancy between the model and the observed bathymetry? Figure $4 \mathrm{c}$ proposes one solution in which the degree of extension in the lower crust would be much higher than that seen in the upper brittle part of the plate. In order to generate additional subsidence extra extension would be required in order to thin the lithospheric plate. This would allow isostacy to cause the high amounts of subsidence observed. Although dynamic effects related to subduction might also explain some of the subsidence anomaly seen in the Woodlark Rift (Lithgow-Bertelloni and Gurnis 1997). I suggest that this example follows the behavior seen in the South China Sea in a similar tectonic setting and forms part of a wider pattern of excess subsidence in margin rift settings associated with break-up.

It is noteworthy that assuming a brittle-to-ductile transition between depths of 10 and $15 \mathrm{~km}$, and assuming normal continental thermal gradients (Zuber et al. 1986), the greatest amounts of lower crustal thinning still have to occur where the greatest amounts of upper crustal extension are observed. Thus, although the extension is not uniform, upper and lower crustal deformation are coupled to some extent. The profile shown in Fig. 4a lies immediately ahead of the seafloor spreading center and represents the state of strain accommodation prior to the onset of seafloor spreading. The example of the Woodlark Basin, therefore, provides us with strong evidence that ductile lower crustal flow is active in advance of final continental breakup in warm arc-type crust environments. 


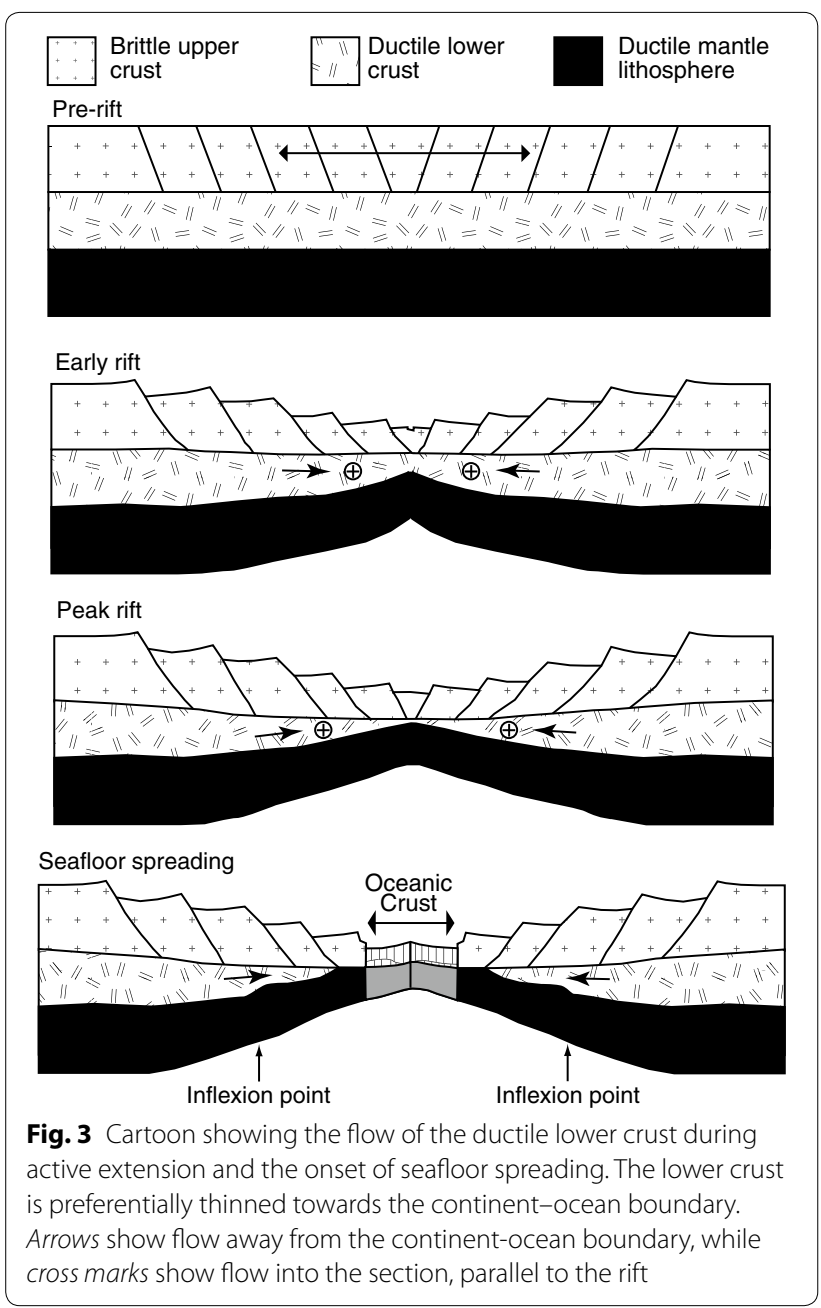

Because there are no corresponding areas of uplift across the rift in the region of the considered cross section it may be inferred that lower crust is being lost in advance of the seafloor spreading center across the entire rift, but particularly in those regions with the highest degrees of extension. Gravitational potential and buoyancy considerations preclude flow of the missing crust back under the thicker crust of the D'Entrecasteaux Islands or Papua New Guinea to the west of the rift axis modeled here. In this case the ductile lower part of the crust is flowing away from the areas of thickened (unextended) crust towards thinner regions in the way that might be anticipated given the gravitational potential, and similar to the situation highlighted by Clark and Royden (2000). The expectation, therefore, would be that continental breakup of thickened arc type crust might often lead to significant degrees of lower crustal flow and to the generation of subsidence anomalies on the order of a kilometer or more.

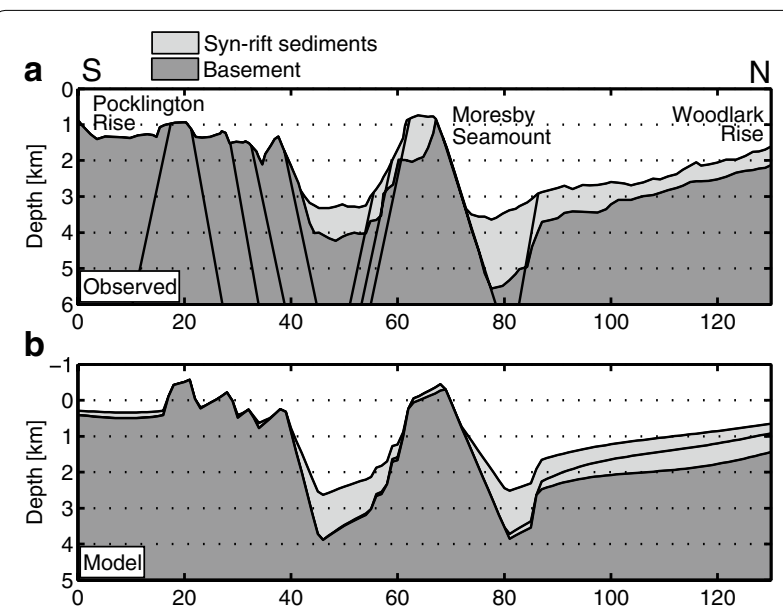

C Upper Crust - Whole Crust $-\quad-15 \mathrm{~km} \mathrm{BDT} \cdots 10 \mathrm{~km}$ BDT

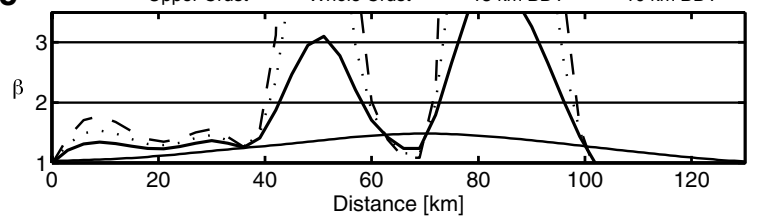

Fig. 4 a Geological cross-section through the Woodlark Basin based on seismic profile from Taylor et al. (1995). b Forward model of the basin predicted from faulting seen in Profile A together with the flexural cantilever model. c Estimates of lower crustal extension compared with total and upper crustal values

\section{Baiyun Sag Basin}

Rifted continental margins often include super-deep extensional basins, as well as the more typical rift basins, that are filled with substantial quantities of sediment and which provide us with the opportunity of understanding when the additional extension has taken place. Although examples like the Woodlark Basin allow us to infer that lower crustal flow must be active during extension prior to the onset of seafloor spreading, the existence of subsidence anomalies in modern passive margins does not preclude some of the flow occurring after the end of extension. Often the timing of preferential extension is unknown. The Baiyun Sag represents a good example of one of these super-deep basins where such questions can be posed.

This particular basin was formed on the outer part of the continental shelf offshore southern China and now preserves around $14 \mathrm{~km}$ of sedimentary rocks overlying a very thin $(\sim 4 \mathrm{~km})$ section of continental crust (Pang et al. 2008; Sun et al. 2008). Recently, this basin was analyzed to determine the degree of excess subsidence, as well as the timing of when this particular subsidence anomaly formed. It has been recognized for some time that much of the subsidence that is observed in this basin occurred after the end of active extension under the continental 


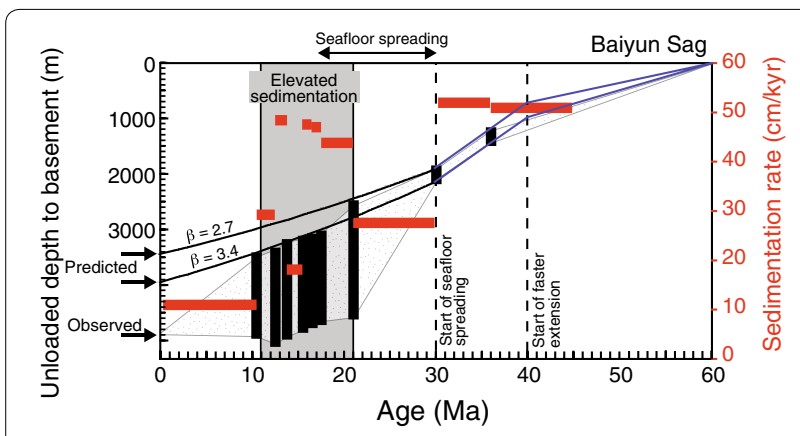

Fig. 5 Reconstructed tectonic subsidence for the central Baiyun Sag showing how the observed depth is substantially higher than that predicted based on syn-rift subsidence. Tectonic subsidence of the basement increases as the rate of sedimentation increases in the early Miocene. Modified from Clift et al. (2015)

shelf, i.e., after $\sim 24 \mathrm{Ma}$ (Clift and Lin 2001; Xie et al. 2014). Various theories have been advanced to explain why such great subsidence has occurred in this particular place, with some arguing that this extra subsidence is related to the intrusion of very dense, mafic magmatic bodies at the base of the crust (Shi et al. 2005). Such models are largely based on seismic reflection images that suggest similarities between this continental margin and those which are known to have been affected by magmatism during breakup, such as Norway or East Greenland (Huang et al. 2005). However, such approaches ignore the fact that magmatic underplating generates permanent uplift of continental margins, not extra subsidence, as has been recognized, for example, across the rifted margins of Northwest Europe (Brodie and White 1994; Hall and White 1994). Unless the magmatic underplating has a density greater than that of the upper mantle asthenosphere then thickening of the crust must lead to permanent uplift not to the subsidence actually observed.

Recently the Baiyun Sag was examined by a subsidence analysis study, which used regional seismic reflection profiles coupled to industrial drill sites that provide age control (Clift et al. 2015). Figure 5 shows one of the reconstructions for a "pseudo-well" in the center of the basin using age and water depth constraints from a nearby exploration well (33-1-1; Fig. 2). The lithology, age, water depth, and thickness information were analyzed using the standard 1-D backstripping approach of Sclater and Christie (1980), which allows the tectonic component of the subsidence history to be isolated, after correcting for sediment loading and sea level variability. It is important to realize that this type of analysis already accounts for the loading of the sediment in driving longterm tectonic subsidence of the basement and is a standard method when examining drilling data in sedimentary basins (Sclater and Christie 1980). In this analysis the potential range of basement depths was shown by vertical bars that are largely a function of the uncertainty in water depths of sedimentation (Fig. 5).

Clift et al. (2015) estimated the amount of subsidence that would be anticipated based on the degree of subsidence that occurred prior to the onset of seafloor spreading, which would normally be considered the syn-rift period (>30 Ma). This prediction was made based on the uniform extension model of McKenzie (1978) with the timing of the onset of seafloor spreading used as the end of the time of maximum continental extension. The results of this analysis suggested that the center of the basin had experienced beta factors of 2.7-3.4. If such values are realistic then it is possible to predict the longterm post-rift, thermal subsidence that occurred after extension ceased. Figure 5 shows that the predicted postrift subsidence results in a basin that is substantially less deep than that actually observed today. Indeed, the predicted curves begin to diverge from the reconstructed depth to basement starting around $20 \mathrm{Ma}$ and now amount to more than $1 \mathrm{~km}$ of anomaly of the unloaded basement depth.

Because the deepening of the basin occurred after the end of active tectonic extension, Clift et al. (2015) proposed that this deepening was caused by lower crustal flow taking place during the post-rift period. Because tectonic-induced deformation of the crust could not be the cause of this flow, they proposed that flow was being driven by loading of the offshore basin by the addition of significant sedimentary loads. This triggered ductile flow when mid crustal viscosities were relatively low. I propose the name "load-flow basin" to describe basins with this type of origin. In this scenario basins that were generated during normal tectonic extension are further deepened as a result of having substantial loads placed into them during the post-rift phase (Fig. 6). Such an explanation had previously been applied to the Malay and Pattani Basins by Morley and Westaway (2006) and had also been proposed in the case of the Pearl River Mouth Basin (Westaway 1994).

Initially such an explanation seems very unlikely because it requires ductile lower crust to move from areas of thin crust back under those parts of the continental margin where crust is thicker, effectively the reverse of what was proposed by Clark and Royden (2000). Such an understanding neglects the fact that the margin is moving out of the state of equilibrium achieved at the end of active extension, as a result of stresses imposed by the erosional processes. Ductile crustal flow towards the rift during active extension will cease as the extension itself finishes and these stresses are relaxed (Fig. 6a). If erosion then results in transfer of mass into the basin center then the equilibrium of the system is again perturbed and 


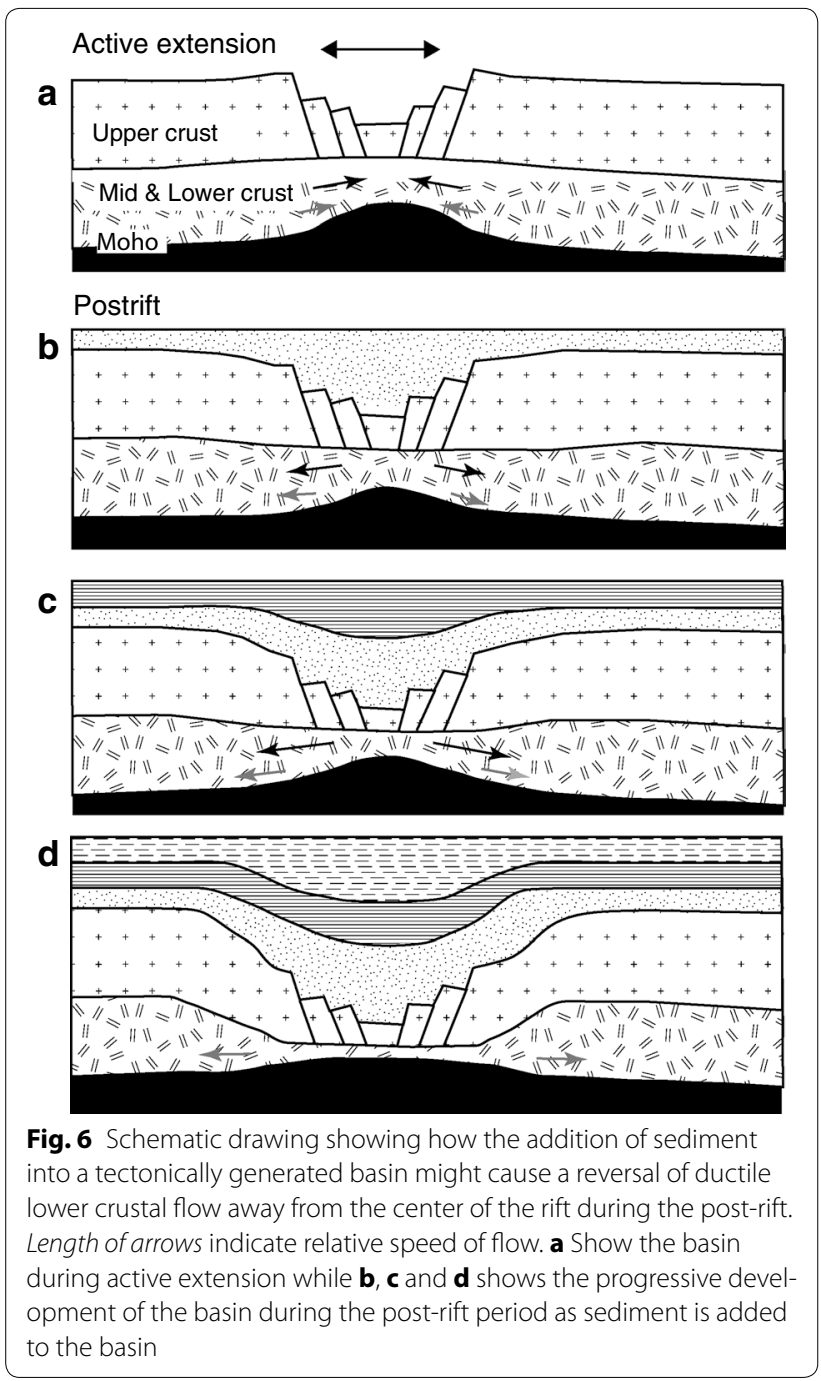

crustal flow may again occur to reestablish a new equilibrium state.

Although we tend to think of isostatic readjustments occurring due to flow in the asthenosphere this need not be the case if the viscosity of the lower crust is the same or even lower than the asthenosphere. Finite element modeling by Clift et al. (2015) showed that provided the lower crustal viscosity is $10^{18}-10^{19} \mathrm{~Pa}$.s, as was estimated for the Pearl River Mouth and adjacent margin, then mid and lower crustal flow of this variety may be significant and that loading might be accommodated by lower crust, not asthenospheric flow. Not surprisingly, the process would be expected to become less important when the lower crust is more rigid and cold.

Clift et al. (2015) proposed that the mid and lower crustal flow was initiated due to a climatically triggered sharp increase in sediment flux on to the continental margin starting around $20 \mathrm{Ma}$, which they associated with an intensification of the East Asian summer monsoon around that time. Whatever the reason for the increase, independent three-dimensional mapping of the continental margin stratigraphy now confirms that accumulation in the Baiyun Sag did increase sharply around this time (Xie et al. 2013). This is a time when there is little evidence for extensional faulting. It is important to understand that this additional tectonic subsidence is not caused just by the loading of the sediment itself, which is accounted for in the backstripping analysis, but instead by the thinning of the underlying crystalline crust caused by the loading.

\section{Other South China Basins}

If this explanation for the extreme subsidence in Baiyun Sag is to be believed then one would expect other basins to show additional tectonic subsidence related to episodes of rapid sediment delivery. These accelerated subsidence phases might not necessarily coincide with phases of subsidence in their neighbors, depending on the sediment distribution and the infilling pattern of the sub-basins themselves. Clift et al. (2015) pointed out the fact that times of anomalous accelerating basement subsidence in the Song Hong-Yinggehai Basin after $\sim 5 \mathrm{Ma}$ could also be correlated with delivery of thick sequences of sediment into the southern part of that basin during the Pliocene-Pleistocene. Again this was a time when there is little evidence for upper crustal extension. South of Hainan a similar pattern appears to taken place after around $10 \mathrm{Ma}$, well after the end of active extension, but during a period of rapid sediment delivery into the Qiongdongnan Basin (Zhao et al. 2013). I anticipate that this process is not limited to basins around the South China Sea and has been recognized in the Gulf of Thailand (Morley and Westaway 2006) and likely in other regions of post-rift subsidence anomalies that have not yet been identified, or have not yet been satisfactorily explained, e.g. Paleozoic passive margin of West North America (Levy and Christie-Blick 1991), the early postrift offshore Gabon, West Africa (Dupré et al. 2007), and the Gulf of Lions, Mediterranean Sea (Burrus et al. 1987).

\section{The role of surface processes}

The modeling presented by Clift et al. (2015) emphasized the importance of the offshore loading in driving lower crustal flow. Because Baiyun Sag is close to the continentocean boundary located $\sim 140 \mathrm{~km}$ to the south the flow was forced northward in a landward direction because the mafic composition of the oceanic crust does not allow this type of flow to occur. This reflects the absence of ductile quartz and the small crustal thickness that keeps temperatures within the crust at relatively cold levels, within the brittle deformation zone. In this review I emphasize 
the importance of processes onshore that accentuate the tendency for the ductile flow to be towards, not away from the continent. Sediment delivered into the offshore basin is largely being derived from erosion of the neighboring landmass; in the case of the Baiyun Sag this is the Pearl River drainage. As the bedrock of southern China is eroded and transformed into sediment, which is then deposited offshore, the underlying rocks are able to exhume as their shallower overburden is removed driven by isostatic stresses. This rock uplift has the effect of increasing the pressure gradient between the offshore and the onshore (Westaway 1994). If we imagine that the system is in equilibrium at the end of the rifting then the simultaneous loading of the offshore coupled with uplift onshore results in a reverse pressure gradient that would drive the flow of ductile crust under the continental margin. Although this means ductile crust flowing from an area of thin crust into an area of thicker crust it is possible because the thin crust created by rifting has effectively become a little thicker, while the thicker crust onshore is becoming a little thinner during the post-rift period.

\section{Onshore erosion}

Low-temperature thermochronology in the form of apatite fission track analyses allows us to estimate the amount of erosion that has occurred across southern China during the Cenozoic. Yan et al. (2009b) indicate that around $4-5 \mathrm{~km}$ of bedrock has been removed over much of the Pearl River drainage and that because the Pearl River has not been involved in large-scale drainage capture, unlike the neighboring large river basins (Brookfield 1998; Zheng et al. 2013; Clift et al. 2006), most of this material has been delivered to the southern Chinese continental margin. Indeed, the amount of erosion appears to be approximately similar to the volume of sediment on the continental margin (Yan et al. 2009a). Although this is not a huge amount of erosion it would have increased the tendency of ductile lower crust to flow towards the area of erosion because of regional rock uplift (Fig. 7), in the same way that focused erosion in the Greater Himalaya is believed to have driven ductile flow towards that mountain range within the ductile "channel" proposed by Beaumont et al. (2001). Because the erosion is less focused in southern China than in the Himalaya we can consider the reaction of the continental margin to erosional unroofing to be a form of channel flow. The process of exhumation and flow would be the same but simply spread out over a wider area as a result of the lack of a topographic front to concentrate the precipitation and, therefore, erosion.

Understanding that these super-deep basins are formed after the extensional phase and not during, it is important when we consider the fact that the present depth of Baiyun Sag could not be produced even if extension had proceeded to an infinite degree in this location, equivalent to seafloor spreading. Uniform extension models suggest that such depths are impossible for a basin of such youth (McKenzie 1978). Such great depths of subsidence are only possible because of continued crustal thinning driven by the flow induced by loading, because the observed depth is greater than is possible given the known age of the basin and assuming uniform extension.

If extension had really proceeded to the point where the beta factor had reached infinity during active extension then one might ask why seafloor spreading did not initiate along the Baiyun Sag rather than towards the south as we know it to have done. The simple answer to this conundrum is that the Baiyun Sag was not so extended at the end of active tectonic extension as it is today but has experienced further thinning after the end of faulting.

\section{Wider implications}

Recognizing this type of extensional basin is important when we consider hydrocarbon exploration along similar continental margins, especially those in Eastern Asia. This is because typical thermal models are based on the concept that after the end of active extension the progressive thickening of the mantle lithosphere results in reduced heatflow and that the heatflow history can be predicted based on the degree of extension which is in turn derived from the subsidence history (McKenzie 1978). However, if the degree of subsidence is much higher than would be predicted then thermal models may be in error because the mantle lithosphere may not be as extended as the lower crust, resulting in thermal models that over-predict heatflow. For example, using the amount of subsidence in the Baiyun Sag as a guide to total lithospheric extension would probably be in error and result in over prediction of heatflow, with serious consequences for our understanding of how hydrocarbon source rocks might have matured in the lower parts of that stratigraphy.

Clearly care needs to be exercised when understanding how strain has been accommodated along continental margins formed where ductile flow may be an important factor. Given typical continental geothermal gradients this should be an influence even on Atlantic passive margins in relatively cold, stable lithosphere, but these effects will be greatly magnified in rift settings where the lithosphere is hotter than usual. As well as the Woodlark Basin, areas like the Gulf of California or the Sea of Japan/East Sea of Korea have likely been influenced by this type of strain accommodation modulated by sedimentation patterns and surface processes. 


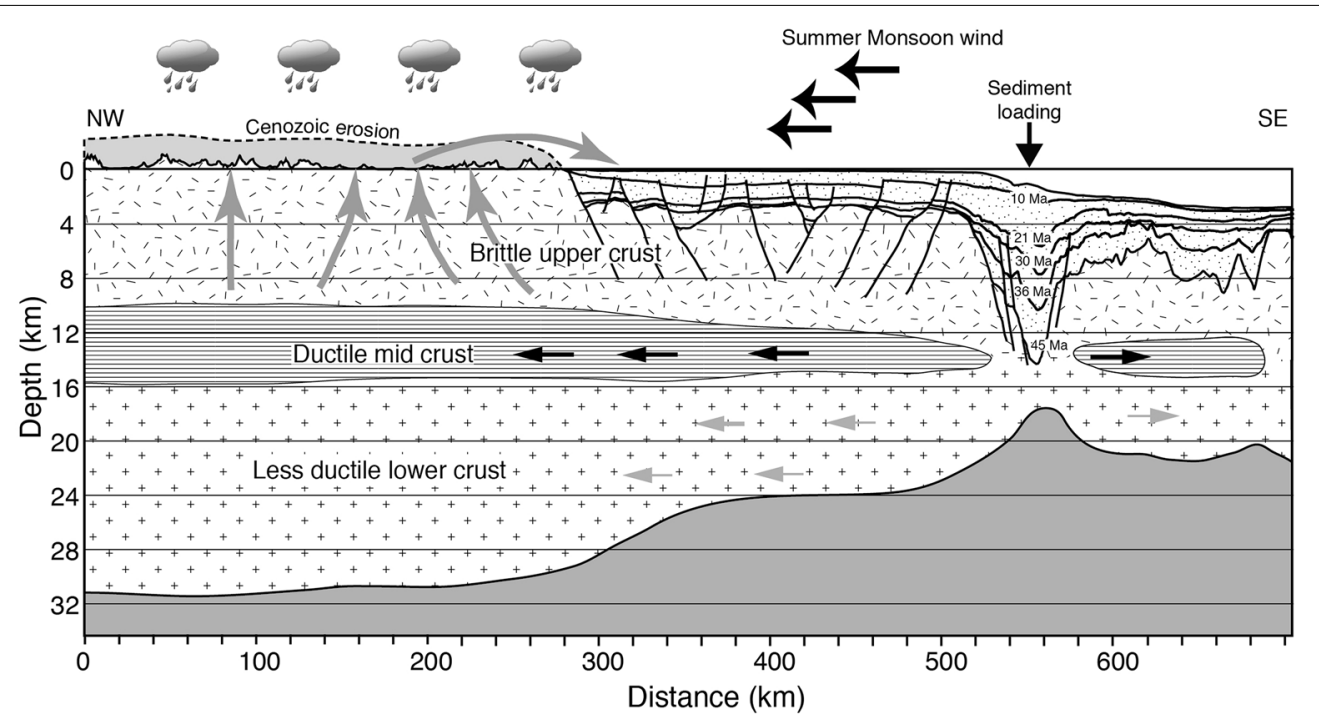

Fig. 7 Cartoon representation of lower crustal flow driven by coupled on shore erosion and offshore loading. Offshore basin structure from Sun et al. (2008), showing reflectors at 10,21, 30, and $36 \mathrm{Ma}$ and basement at $45 \mathrm{Ma}$. Crustal thickness is derived from seismic refraction data of Nissen et al. (1995). Black arrows indicate laminar flow in the quartz-bearing mid crust while gray arrows show slower ductile flow in the feldspathic lower crust

It is also worth noting the fact that continental sediment distribution systems will also affect passive margin structure. Large-scale reorganization of drainage systems is well documented across much of East and Southeast Asia (Clift et al. 2006; Zheng et al. 2013; Robinson et al. 2013) and because this process of drainage capture is driven largely by topographic uplift of the Tibetan Plateau this means that the tectonics of the continental interior is guiding where large sediment masses are being deposited and preserved on the continental margins, with some additional control exercised by the location and timing of basin formation around the continental margins that generate suitable sediment traps. As a result topographic uplift in Eastern Tibet and the resultant reorganization of drainage patterns will also have an effect on the subsequent crustal flow and structure of rifted passive margins around East Asia.

\section{Conclusions}

Strain accommodation in passive continental margins does not follow the typical rules used to understand extension in intra-continental extensional basins. It has long been recognized that uniform extension models do not apply well to passive margin systems and that excess subsidence is often recognized, exceeding that which would be predicted based on brittle upper crustal normal faulting. Efforts to apply simple shear models to passive margins have had limited success as they often predict contrasting subsidence patterns, which are rarely observed in the predicted fashion observe in practice. In rifts affecting thick and/or warmer than normal continental crust (i.e., $\sim 35$ to $40 \mathrm{~km}$ thick) (Christensen and Mooney 1995), lower and mid crustal ductile flow may be invoked to account for the excessive amounts of subsidence seen close to the continentocean transition. Flow of this variety has long been recognized in wide rift settings, like the Basin and Range, as well as under orogenic regions such as the Tibetan Plateau, and would be anticipated in warm rifts based on our understanding of the physical characteristics of major rock-forming minerals and the thermal structure of the lithosphere.

Crustal flow during continental breakup appears to be away from the continent and towards the propagating rift, as shown around the South China Sea, as well as in the Woodlark Basin of the Southwest Pacific. However, studies of sediment-filled basins around the margins of South China Sea show that some of the anomalous subsidence occurs after the end of active tectonic extension, requiring a mechanism unrelated to break-up tectonics to explain the anomalous depths of these structures. Finite element modeling now indicates that loading of the basins with rapidly delivered siliciclastic sediment may be responsible for driving lower crustal flow back towards the continent and away from the centers of these super-deep basins (Clift et al. 2015). The flow in the ductile crust is driven by a combination of loading in the offshore and rock uplift onshore, which is the response to erosional unroofing. The landward ductile crustal flow proposed in the Baiyun Sag, Song Hong-Yinggehai, and 
Qiongdongnan Basins occurs at different times, reflecting the contrasting periods of rapid sedimentation in each of these areas. Similar processes are inferred to have occurred in the Gulf of Thailand and under the Sunda Shelf (Morley and Westaway 2006) and ought to be common worldwide in similar tectonic settings.

Ductile lower crustal flow affects not only orogenic belts in collision settings but also rifted passive margins. Surface processes, modulated by climatic evolution, may be important in exerting stresses on the crust, which may drive this ductile flow. Much as focused erosion controls uplift and exhumation in the Himalaya, so more diffuse erosion can also drive flow in passive margin settings and help control the structure of continental margins. Such types of deformation might be considered to affect all rifts that are warm enough to allow large-scale lower and mid crustal flow. This represents a new type of climatetectonic coupling previously unrecognized.

\section{Author details}

1 Department of Geology and Geophysics, Louisiana State University, Baton Rouge, LA 70803, USA. ${ }^{2}$ Key Laboratory of Marginal Sea Geology, South China Sea Institute of Oceanology, 164 West Xingang Road, Guangzhou 510301, China.

\section{Acknowledgements \\ I wish to acknowledge the financial assistance from AOGS to attend the 2015 meeting in Singapore. Sascha Brune, Patricia Persaud, and Chris Morley contributed to the development of some of the ideas presented in this paper I thank G.J.H. Oliver, Lloyd White, and an anonymous reviewer for thoughtful reviews. The Charles T. McCord Jr. chair in petroleum geology at Louisiana State University supported my research.}

\section{Competing interests}

The author declares that he has no competing interests.

Received: 3 September 2015 Accepted: 28 October 2015

Published online: 14 November 2015

\section{References}

Abers GA. Evidence for seismogenic normal faults at shallow depths in continental rifts. In: Wilson RCL, Whitmarsh RB, Taylor B, Froitzheim N, editors. Non-volcanic rifting of continental margins: a comparison of evidence from land and sea, vol. 187., Special PublicationLondon: Geological Society; 2001. p. 305-18.

Baldwin SL, Fitzgerald PG, Webb LE. Tectonics of the New Guinea Region. Ann Rev Earth Planet Sci. 2012;40:495-520.

Barckhausen U, Engels M, Franke D, Ladage S, Pubellier M. Evolution of the South China Sea: revised ages for breakup and seafloor spreading. Mar Petrol Geol. 2014. doi:10.1016/j.marpetgeo.2014.02.022

Beaumont C, Jamieson RA, Nguyen MH, Lee B. Himalayan tectonics explained by extrusion of a low-viscosity crustal channel coupled to focused surface denudation. Nature. 2001;414(6865):738-42.

Boillot G, Girardeau J, Kornprobst J. Rifting of the Galicia Margin: crustal thinning and emplacement of mantle rocks on the seafloor. Proc Ocean Drill Prog Pt A Init Rpt. 1988;103:741-56.

Briais A, Patriat P, Tapponnier P. Updated interpretation of magnetic anomalies and seafloor spreading stages in the South China Sea: implications for the tertiary tectonics of Southeast Asia. J Geophys Res. 1993;98:6299-328. doi:10.1029/92JB02280.

Brodie J, White N. Sedimentary basin inversion caused by igneous underplating: Northwest European continental shelf. Geology. 1994;22:147-50.
Brookfield ME. The evolution of the great river systems of southern Asia during the Cenozoic India-Asia collision; rivers draining southwards. Geomorphology. 1998;22(3-4):285-312.

Buck WR. Modes of continental lithospheric extension. J Geophys Res. 1991;96:20161-78.

Burov EB, Watts AB. The long-term strength of continental lithosphere: "jelly sandwich" or "crème brûlée"? GSA Today. 2006;16(1):4-10. doi:10.1130/1052-5173(2006)016.

Burrus J, Bessis F, Doligez B. Heat Flow, Subsidence and crustal structure of the Gulf of Lions (NW Mediterranean): a quantitative discussion of the classic passive margin model. In: Beaumont C, Tankard AJ, editors. Sedimentary basins and basin-forming mechanisms, vol. 12. Canada: Canadian Society of Petroleum Geologists; 1987. p. 1-15.

Christensen NI, Mooney WD. Seismic velocity structure and composition of the continental crust; a global view. J Geophys Res. 1995;100:9761-88.

Clark MK, Royden LH. Topographic ooze: building the eastern margin of Tibet by lower crustal flow. Geology. 2000;28:703-6.

Clift P, Lin J. Preferential mantle lithospheric extension under the South China margin. Mar Petrol Geol. 2001;18(8):929-45.

Clift P, Lin J, Barckhausen U. Evidence of low flexural rigidity and low viscosity lower continental crust during continental break-up in the South China Sea. Mar Petrol Geol. 2002;19(8):951-70.

Clift PD, Blusztajn J, Nguyen DA. Large-scale drainage capture and surface uplift in eastern Tibet-SW China before 24 Ma inferred from sediments of the Hanoi Basin, Vietnam. Geophys Res Lett. 2006; doi:10.1029/200 6GL027772.

Clift PD, Brune S, Quinteros J. Climate changes control offshore crustal structure at South China Sea continental margin. Earth Planet Sci Lett. 2015;420:66-72. doi:10.1016/j.epsl.2015.03.032.

Clift PD, Lee GH, Nguyen AD, Barckhausen U, Hoang VL, Sun Z. Seismic evidence for a dangerous grounds mini-plate: no extrusion origin for the South China Sea. Tectonics. 2008; doi:10.1029/2007TC002216.

Davis M, Kusznir NJ. Depth-dependent lithospheric stretching at rifted continental margins. In: Karner GD, editor. Proceedings of NSF Rifted Margins Theoretical Institute. New York: Columbia University Press; 2004. p. 92-136.

Doglioni C, Ismail-Zadeh A, Panza G, Riguzzi F. Lithosphere-asthenosphere viscosity constrast and decoupling. Phys Earth Planet Inter. 2011;189(1-2):1-8.

Driscoll NW, Karner GD. Lower crustal extension across the Northern Carnarvon basin, Australia: evidence for an eastward dipping detachment. J Geophys Res. 1998;103:4975-91.

Dupré SP, Bertotti G, Cloetingh S. Tectonic history along the South Gabon Basin: anomalous early post-rift subsidence. Mar Petrol Geol. 2007:24(3):151-72. doi:10.1016/j.marpetgeo.2006.11.003.

Franke D, Savva D, Pubellier M, Steuer S, Mouly B, Auxietre J-L, Meresse F, Chamot-Rooke N. The final rifting evolution in the South China Sea. Mar Petrol Geol. 2014;58B:704-20. doi:10.1016/j.marpetgeo.2013.11.020.

Gilder SA, Gill JB, Coe RS, Zhao X, Liu Z, Wang G, Yuan K, Liu W, Kuang G, Wu H. Isotopic and paleomagnetic constraints on the Mesozoic tectonic evolution of South China. J Geophys Res. 1996;101:16137-55.

Godin L, Grujic D, Law RD, Searle MP. Channel flow, ductile extrusion and exhumation in continental collision zones; an introduction. In: Law RD, Searle MP, Godin L, editors. Channel flow, ductile extrusion, and exhumation of lower-middle crust in continental collision zones, vol. 268., Special PublicationLondon: Geological Society; 2006. p. 1-23.

Hall BD, White N. Origin of anomalous tertiary subsidence adjacent to North Atlantic continental margins. Mar Petrol Geol. 1994;11(6):702-14. doi:10.1016/0264-8172(94)90024-8.

Harris N. Channel flow and the Himalayan-Tibetan orogen: a critical review. J Geol Soc, Lond. 2007;164(3):511-23. doi:10.1144/0016-76492006-133.

Harrison TM. Did the Himalayan Crystallines extrude partially molten from 237 beneath the Tibetan Plateau? In: Law RD, Searle MP, Godin L, editors, Channel flow, ductile extrusion, and exhumation of lower-middle crust in continental collision zones, vol. 268., vol Special PublicationLondon: Geological Society; 2006. p. 237-54.

Hayes DE, Nissen SS, Buhl P, Diebold J, Bochu Y, Weijun Z, Yongqin C. Throughgoing crustal faults along the northern margin of the South China Sea and their role in crustal extension. J Geophys Res. 1995;100:22435-46.

Hinz K, Fritsch J, Kempter EHK, Mohammad AM, Meyer J, Mohamed D, Vosberg $\mathrm{H}$, Weber J, Benavidez J. Thrust tectonics along the north-western continental margin of Sabah/Borneo. Geol Rund. 1989;78(3):705-30. 
Hodges K. A synthesis of the channel flow-extrusion hypothesis as developed for the Himalayan-Tibetan orogenic system. In: Law RD, Searle MP, Godin $L$, editors. Channel flow, ductile extrusion, and exhumation of lower-middle crust in continental collision zones, vol. 268., vol Geological Society Special PublicationLondon: Geological Society; 2006. p. 71-90.

Huang CJ, Zhou D, Sun Z, Chen CM, Hao HJ. Deep crustal structure of Baiyun Sag, northern South China Sea revealed from deep seismic reflection profile. Chinese Sci Bull. 2005;50(11):1131-8.

Hutchison CS, Bergman SC, Swauger DA, Graves JE. A Miocene collisional belt in north Borneo: uplift mechanism and isostatic adjustment quantified by thermochronology. J Geol Soc Lond. 2000;157:783-93.

Hutchison CS, Vijayan VR. What are the Spratly Islands? J Asian Earth Sci. 2010;39(5):371-85. doi:10.1016/j.jseaes.2010.04.013.

Kington JD, Goodliffe AM. Plate motions and continental extension at the rifting to spreading transition in Woodlark Basin, Papua New Guinea: can oceanic plate kinematics be extended into continental rifts? Tectonophysics. 2008;458:82-95.

Kusznir NJ, Egan SS. Simple-shear and pure-shear models of extensional sedimentary basin formation: application to the Jean d'Arc basin, Grand Banks of Newfoundland. In: Tankard AJ, Balkwill HR, editors. Extensional tectonics and stratigraphy of the North Atlantic margins, vol. 46., MemoirTulsa: American Association of Petroleum Geologists; 1989. p. 305-22.

Kusznir NJ, Marsden G, Egan SS. A flexural cantilever simple shear/pure shear model of continental extension. In: Roberts AM, Yielding G, Freeman B, editors. The geometry of normal faults, vol. 56., Special PublicationLondon: Geological Society; 1991. p. 41-61.

Levy M, Christie-Blick N. Tectonic subsidence of the early Paleozoic passive continental margin in Easton California and Southern Nevada. Geol Soc Am Bull. 1991;103:1590-606.

Lister GS, Etheridge MA, Symonds PA. Detachment models for the formation of passive continental margins. Tectonics. 1991;10:1038-64.

Lithgow-Bertelloni C, Gurnis M. Cenozoic subsidence and uplift of continents from time-varying dynamic topography. Geology. 1997;25:735-8.

Little TA, Baldwin SL, Fitzgerald PG, Monteleone BD. Continental rifting and metamorphic core complex formation ahead of the Woodlark spreading ridge, D’Entrecasteaux Islands, Papua New Guinea. Tectonics. 2007; doi:10. 1029/2005TC001911.

McKenzie D, Nimmo F, Jackson JA, Gans PB, Miller EL. Characteristics and consequences of flow in the lower crust. J Geophys Res. 2000;105(B5):11029-46.

McKenzie DP. Some remarks on the development of sedimentary basins. Earth Planet Sci Lett. 1978;40:25-32.

Morley CK, Westaway R. Subsidence in the super-deep Pattani and Malay basins of Southeast Asia: a coupled model incorporating lower-crustal flow in response to post-rift sediment loading. Basin Res. 2006;18:51-84. doi:10.1111/j.1365-2117.2006.00285.x.

Mutter JC, Mutter CZ, Fang J. Analogies to oceanic behaviour in the continental breakup of the western Woodlark Basin. Nature. 1996;380:333-6.

Nissen SS, Hayes DE, Buhl P, Diebold J, Yao B, Zeng W, Chen Y. Deep penetration seismic soundings across the northern margin of the South China Sea. J Geophys Res. 1995;100(B11):22407-33.

Pang X, Chen C, Peng D, Zhou D, Shao L, He M, Liu B. Basic geology of Baiyun deep-water area in the northern South China Sea. China Offshore Oil Gas. 2008;4:215-22.

Pérez-Gussinyé M, Morgan JP, Reston TJ, Ranero CR. The rift to drift transition at non-volcanic margins: insights from numerical modelling. Earth Planet Sci Lett. 2006;244(1-2):458-73. doi:10.1016/j.epsl.2006.01.059.

Roberts AM, Yielding G, Kusznir NJ, Walker I, Dorn-Lopez D. Mesozoic extension in the North Sea: Constraints from flexural backstripping, forward modelling and fault populations. In: Parker JR, Petroleum Geology of NW Europe, editors. Proceedings of the 4th Conference. London: Geological Society; 1993. p. 1123-36.

Robinson RAJ, Brezina CA, Parrish RR, Horstwood MSA, Oo NW, Bird MI, Thein $M$, Walters AS, Oliver GJH, Zaw K. Large rivers and orogens: the evolution of the Yarlung Tsangpo-Irrawaddy system and the eastern Himalayan syntaxis. Gondwana Res. 2013; doi:10.1016/j.gr.2013.07.002.

Royden L, Keen CE. Rifting processes and thermal evolution of the continental margin of eastern Canada determined from subsidence curves. Earth Planet Sci Lett. 1980;51:714-7.

Ru K, Pigott JD. Episodic rifting and subsidence in the South China Sea. AAPG Bull. 1986;70(9):1136-55.
Rudnick RL, Fountain DM. Nature and composition of the continental crust; a lower crustal perspective. Rev Geophys. 1995;33:267-309.

Sclater JG, Christie PAF. Continental stretching: an explanation of the post Mid-Cretaceous subsidence of the central North Sea basin. J Geophys Res. 1980;85:3711-39.

Shi X, Burov E, Leroy S, Qiu X, Xia B. Intrusion and its implication for subsidence: a case from the Baiyun Sag, on the northern margin of the South China Sea. Tectonophysics. 2005;407(1-2):117-34. doi:10.1016/j. tecto.2005.07.004.

Smith JV. Feldspar minerals: crystal structure and physical properties 1. Springer Science and Business Media, Berlin. 2013. doi:10.1007/978-3-642-96173-1.

Su D, White N, McKenzie D. Extension and subsidence of the Pearl River mouth basin, northern South China Sea. Basin Res. 1989;2:205-22.

Sun Z, Zhong Z, Zhou D, Pang X, Huang CC, Chen C, He M, Xu H. Dynamics analysis of the Baiyun Sag in the Pearl River Mouth Basin. North of the South China Sea. Acta Geol Sin. 2008;82(1):73-83.

Tankard AJ, Welsink HJ. Extensional tectonics and stratigraphy of Hibernia oil field, Grand Banks, Newfoundland. AAPG Bull. 1987;71:1210-32.

Taylor B, Goodliffe AM, Martinez F, Hey RN. Continental riting and initial seafloor spreading in the Woodlark basin. Nature. 1995;374:534-7.

Tullis J. High temperature deformation of rocks and minerals. Rev Geophys Space Phys. 1979;17:1137-54.

Walsh J, Watterson J, Yielding G. The importance of small-scale faulting in regional extension. Nature. 1991;351:391-3.

Webb AAG, Yin A, Harrison TM, Célérier J, Burgess WP. The leading edge of the Greater Himalayan Crystalline complex revealed in the NW Indian Himalaya: implications for the evolution of the Himalayan orogen. Geology. 2007;35(10):955-8. doi:10.1130/G23931A.1.

Weissel JK, Taylor B, Karner GD. The opening of the Woodlark Basin, subduction of the Woodlark spreading system, and the evolution of Northern Melanesia since mid-Pliocene time. Tectonophysics. 1982;87(1-4):253-77.

Wernicke B. Uniform sense of normal simple shear of the continental lithosphere. Can J Earth Sci. 1985;22:108-25.

Westaway R. Re-evaluation of extension across the Pearl River Mouth Basin, South China Sea: implications for continental lithosphere deformation mechanisms. J Struct Geol. 1994;16:823-38.

Whitmarsh RB, Manatschal G, Minshull TA. Evolution of magma-poor continental margins from rifting to seafoor spreading. Nature. 2001;413:150-4.

Xie H, Zhou D, Li Y, Pang X, Li P, Chen G, Li F, Cao J. Cenozoic tectonic subsidence in deepwater sags in the Pearl River Mouth Basin, northern South China Sea. Tectonophysics. 2014;615-616:182-98. doi:10.1016/j. tecto.2014.01.010.

Xie H, Zhou D, Pang X, Li Y, Wu X, Qiu N, Li P, Chen G. Cenozoic sedimentary evolution of deepwater sags in the Pearl River Mouth Basin, northern South China Sea. Mar Geophys Res. 2013;34:159-73. doi:10.1007/ s11001-013-9183-7.

Yan Y, Carter A, Xia B, Ge L, Brichau S, Xiaoqiong H. A fission-track and (U-Th)/ He thermochronometric study of the northern margin of the South China Sea: an example of a complex passive margin. Tectonophysics. 2009a;474:584-94.

Yan Y, Hu X, Lin G, Xia B, Li X, Patel RC. Denudation history of South China block and sediment supply to northern margin of the South China Sea. J Earth Sci. 2009b; doi:10.1007/s12583-009-0006-3.

Zhao Z, Sun Z, Wang Z, Sun Z, Liu J, Wang Z, Sun L. The dynamic mechanism of post-rift accelerated subsidence in Qiongdongnan Basin, northern South China Sea. Mar Geophys Res. 2013;34:295-308. doi:10.1007/ s11001-013-9188-2.

Zheng H, Clift PD, Tada R, Jia JT, He MY, Wang P. A Pre-Miocene birth to the Yangtze River. Proc Nat Acad Sci. 2013. doi:10.1073/pnas.1216241110.

Zhu B-Q, Wang H-F, Chen Y-W, Chang X-Y, Hu Y-G, Xie J. Geochronological and geochemical constraint on the Cenozoic extension of Cathaysian lithosphere and tectonic evolution of the border sea basins in East Asia. J Asian Earth Sci. 2004;24(2):163-75.

Zuber MT, Parmentier EM, Fletcher RC. Extension of continental lithosphere: a model for two scales of Basin and Range deformation. J Geophys Res. 1986;91:4826-38. 